\title{
Estimulação magnética transcraniana de repetição (EMTR) na redução do consumo de cocaína
}

\author{
Repetitive transcranial magnetic stimultion (rtms) \\ in reducing cocaine use
}

\section{Maria Isabel Brazil Protasio' ${ }^{1}$ João Paulo Lyra da Silva ${ }^{2}$ (1)}

${ }^{1}$ Autora para correspondência. Grupo Neurofocus (Rio de Janeiro). Rio de Janeiro, Brasil. isabelbrazil@gmail.com ${ }^{2}$ Grupo Neurofocus (Rio de Janeiro). Rio de Janeiro, Brasil. silva.jpl.1957@gmail.com

RESUMO | INTRODUÇÃO: Não há medicamentos aprovados para tratamento do uso nocivo da cocaína ${ }^{1}$, relevante e complexo problema de saúde pública, o que gera demanda por formas efetivas de tratamento biológico. O uso terapêutico da estimulação magnética transcraniana de repetição (EMTr) para reduzir o consumo de substâncias psicoativas vem sendo explorado desde 200323.

Em revisão integrativa publicada em 2019, constatou-se a existência de sete estudos experimentais que indicavam, no conjunto, efeitos benéficos do uso da técnica nos usuários ${ }^{4}$. Desde então, novos estudos tanto experimentais quanto observacionais têm sido publicados sobre o tema. Neles, novos desfechos foram examinados, como melhoria do sono, em estudo observacional, e da desregulação hedônica, em estudo experimental. Nota-se, a partir desses trabalhos, um horizonte mais palpável de aplicação clínica da EMTr no tratamento da adição à cocaína na saúde pública. OBJETIVO: Apresentar os resultados de estudos que avaliaram a eficácia da EMTr na redução do consumo de cocaína desde a revisão de 20194. MÉTODO: O estudo de Protasio e colaboradores $^{4}$ relata revisão integrativa de sete ensaios realizados de 2007 a 2016, que investigam o uso de EMTr em indivíduos que abusam da cocaína. A fim de atualizar achados de pesquisa sobre 0 tema, foi realizada, de forma independente pelos autores, busca de publicações referentes a estudos epidemiológicos de 2017 até o momento que avaliaram a utilização de EMTr para o tratamento de indivíduos que abusavam do uso da cocaína. A busca foi realizada nos sistemas de busca PubMed/Medline e Google Acadêmico, tendo sido utilizados os termos: Transcranial Magnetic Stimulation AND Cocaine use disorder. A busca no Google Acadêmico foi considerada até a $4^{a}$. página por irrelevância ao tema nas duas páginas que se seguiram. (Figura. 1) RESULTADOS: Foram encontrados sete estudos, quatro experimentais e três observacionais. Em dois estudos, a irradiação foi profunda, e, nos outros, superficial. A estimulação Theta Burst foi usada em dois estudos. O córtex pré-frontal dorso-lateral esquerdo (CPFDLE) foi o alvo de escolha em cinco estudos. Em um estudo, foram aplicados 2000 pulsos e em três, 2400 pulsos por sessão; em um, 1200 e em outros dois, 600 pulsos ou menos. Em seis estudos, foi observada redução do consumo de cocaína (Quadro 1). 


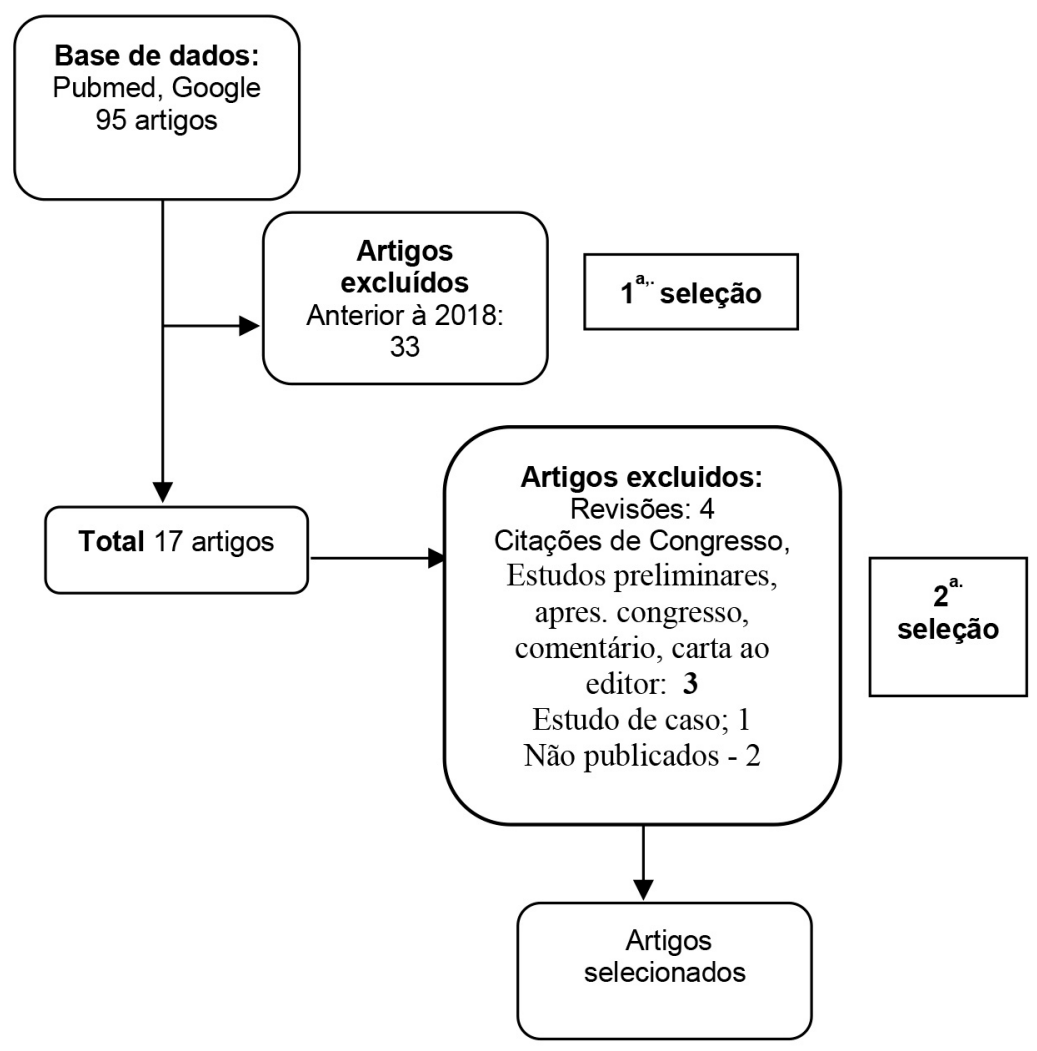


Quadro 1. Ensaios experimentais de dados usando rTMS em dependentes de cocaína $a^{5-11}$

\begin{tabular}{|c|c|c|c|c|c|c|c|}
\hline Estudos & Desenhos & N & Sessões & Parâmetros & Controles (C) & $\begin{array}{c}\text { Efeitos } \\
\text { Adversos }\end{array}$ & Resultados \\
\hline 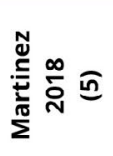 & $\begin{array}{l}\text { Estudo piloto } \\
\text { controlado }\end{array}$ & $\begin{array}{l}18 \text { em três } \\
\text { grupos } \\
\text { (6 EMTrp } \\
\text { AF, } 6 \mathrm{BF}, 6 \mathrm{C})\end{array}$ & 13 & $\begin{array}{l}1200 \text { pls } 10 \mathrm{~Hz} \text { ou } 900 \mathrm{pls} \\
1 \mathrm{~Hz} 40 \text { trains EMTrp } \\
10 \mathrm{H} / 90-110 \% \text { LM, } 3 \\
\text { pls/20s CPFM e CCA }\end{array}$ & Bobina placebo & $\begin{array}{l}\text { Desconforto a } 120 \% \mathrm{LM} \text {, } \\
\text { antes do início do estudo }\end{array}$ & $\begin{array}{l}\text { Redução da escolha por cocaína no grupo EMTr } \\
\text { alta freq.* (ses.2 e 3); sem diferença nos outros } \\
\text { grupos }\end{array}$ \\
\hline 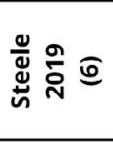 & Estudo aberto & 19 & \begin{tabular}{|l}
30 \\
2/dia
\end{tabular} & $\begin{array}{l}600 \text { pls TBSi (3pls } 50 \mathrm{~Hz}) \\
100 \% \text { LM } \\
200 \mathrm{~ms}(5 \mathrm{~Hz}) \text { trains } 2 \mathrm{~s} \text { a } \\
\text { cada 8s/190s. CPFDL E. } \\
\end{array}$ & - & $\begin{array}{l}\text { Cefaleia leve na maioria; } \\
\text { não toleraram }(n=2)\end{array}$ & $\begin{array}{l}9 \text { pac. foram analisados. Redução do número de } \\
\text { dias de uso***; redução do gasto de dinheiro com } \\
\text { cocaína**; sem diferença qualitativa no consumo } \\
\text { de cocaína; }\end{array}$ \\
\hline 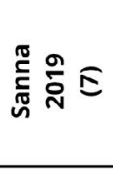 & Estudo piloto & $\begin{array}{l}25 \text { TBSi } \\
22 \text { EMTrp }\end{array}$ & \begin{tabular}{|l}
20 \\
$\left(10\right.$ sems $1^{\mathrm{a}} \mathrm{sem}-$ \\
$2 /$ dia/1int. +4 \\
sess. \\
$1 /$ dia/2sems $)$ \\
\end{tabular} & $\begin{array}{l}\text { 600pls - TBSi (3 pls } 50 \mathrm{~Hz}) \\
200-\mathrm{ms} \text { intervals for } 2 \mathrm{~s}- \\
(5 \mathrm{~Hz}) \text {. trains de } 2 \mathrm{~s} \mathrm{a} \\
\text { cada } 10 \mathrm{~s} / 190 \mathrm{~s} / . \mathrm{CPF} \\
\text { bilateral }\end{array}$ & \begin{tabular}{|l|}
2400 pls. 40 trains \\
EMTrp $15 \mathrm{~Hz} 60$ \\
pls/4s/15s int. \\
CPF bilateral $(20$ \\
sess.)
\end{tabular} & $\begin{array}{l}\text { Pequeno desconforto em } \\
\text { ambas as técnicas no início } \\
\text { da estimulação }\end{array}$ & $\begin{array}{l}\text { Redução do consumo* em ambas as técnicas, } \\
\text { s/diferença entre elas. Redução da fissura *** em } \\
\text { ambas as técnicas no fator tempo, mas não no } \\
\text { tratamento. }\end{array}$ \\
\hline 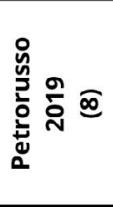 & Estudo aberto & 16 & $\begin{array}{l}28 \\
(20 \text { fase intensa } \\
8 \text { fase manut. } \\
2 \text { sess /dia } 13 \mathrm{~m} \\
\text { int). }\end{array}$ & $\begin{array}{l}\text { 2400pls 40trains EMTr } \\
\text { 15hz/100\% LM } \\
60 / 15 s \text { int.CPFDL E. }\end{array}$ & - & $\begin{array}{l}\text { Sem efeitos } \\
\text { Adversos }\end{array}$ & $\begin{array}{l}4 \text { semanas após EMTr redução do consumo** em } \\
9 \text { participantes (56,25\% urina negativo); } \\
\text { red.sintomas de abstinência Lb-2** e } 4 \mathrm{~ms} \text { **; red. } \\
\text { fissura* Lb }-4 \text { meses*, sem diferença entre Lb e } 2 \\
\text { ms; dim, anedonia Lb-2 e } 4 \text { meses, dim. ansied.Lb- } \\
2 \mathrm{~m}^{\star \star} 4 \mathrm{~ms}^{\star \star \star} \text {; sem diferença para insônia. }\end{array}$ \\
\hline 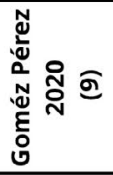 & $\begin{array}{l}\text { Estudo aberto } \\
\text { retrospectivo } \\
\text { observacional } \\
\text { randomizado }\end{array}$ & 87 & $\begin{array}{l}34 \\
(10 \text { em } 5 \text { dias }+ \\
24 \text { em } 12 \text { sems } \\
\text { (2 sess/dia } 45- \\
60 \mathrm{~m} \text { int.). } \\
\end{array}$ & $\begin{array}{l}\text { 2400pls 40trains EMTr } \\
\text { 15hz/100\% LM } \\
60 / 15 \text { s int.CPFDL E. }\end{array}$ & $\begin{array}{l}10 \text { pacientes em } \\
\text { lista de espera } \\
\text { que receberam } \\
\text { EMTr. }\end{array}$ & $\begin{array}{l}\text { Sem efeitos } \\
\text { Adversos }\end{array}$ & $\begin{array}{l}\text { Redução do consumo } * * \star 30 \text { d. (71.9\%) 90d. (66\%) } \\
\text { após EMTr, melhora na qualidade do sono }{ }^{\star \star *} \text { que } \\
\text { se manteve por } 90 \text { dias após EMTr/ associado à } \\
\text { quantidade de sessões EMTr; red. da fissura*** }\end{array}$ \\
\hline 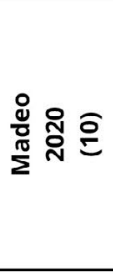 & $\begin{array}{l}\text { Estudo cohort } \\
\text { retrospectivo } \\
\text { observacional }\end{array}$ & 284 & $\begin{array}{l}\text { (10 em } 5 \text { dias }+ \\
24 \text { em } 12 \text { sems } \\
\text { (2 sess/dia } 13 \mathrm{~m} \\
\text { int.). }\end{array}$ & $\begin{array}{l}\text { 2400pls 40trains EMTr } \\
\text { 15hz/100\% LM } \\
60 / 15 \text { s int. CPFDL E. }\end{array}$ & \begin{tabular}{|l|} 
Tempo de \\
recaída 174 \\
pacientes em \\
tto.tradicional 15 \\
anos antes nos \\
USA.
\end{tabular} & $\begin{array}{l}\text { Cefaleia 23, hipomania 4, } \\
\text { ansiedade 2, irrit.2, dor de } \\
\text { dente 2, desconforto 1, } \\
\text { angioedema e urticária 1, } \\
\text { distração 1, tontura 1, } \\
\text { náusea 1, náusea e } \\
\text { dormência 1, convulsão 1, } \\
\text { episódio hipomaníaco 1. }\end{array}$ & $\begin{array}{l}\text { Aumento do tempo de abstinência (91 dias) ( } 95 \% \\
\text { intervalo de confiança } 70-109 \text { dias) em relação à } \\
\text { pacientes em tratamento tradicional (51) (intervalo } \\
\text { de confiança de } 95 \% 39-78 \text { dias). Diferença se } \\
\text { mostrou } 80 \text { dias após alta hospitalar. }\end{array}$ \\
\hline ㅇํํ유ํ & $\begin{array}{l}\text { Estudo } \\
\text { retrospectivo } \\
\text { investigativo }\end{array}$ & 10 & $\begin{array}{l}10 \text { sessões } \\
\text { durante } 2 \\
\text { semanas }\end{array}$ & $\begin{array}{l}2000 \text { pls } 20 \text { trains EMTr } \\
15 \mathrm{~Hz} / 100 \% \mathrm{LM}, 30 \mathrm{~s} / 2 \mathrm{~s} \\
\text { int. } \\
\text { CPFDL E. }\end{array}$ & - & - & $\begin{array}{l}\text { Redução da fissure **, redução dos escores de } \\
\text { depressão *, sem diferença no escore de } \\
\text { ansiedade. }\end{array}$ \\
\hline
\end{tabular}

$p \leq 0.05 * ; p \leq 0.01 * * ; p \leq 0.001 * * *$

Key: AF - alta frequência; BF - baixa frequência; C -Controle; EMTr - Estimulação Magnética Transcraniana repetitiva; EMTrp - EMTr profunda; TBSc - theta burst stimulation cotínua; TBS - theta busrt intermitente; CPF - córtex prefrontal; CPFDL - cortex prefrontal dorsolateral; CPFM - cortex; pré-frontal medial; CCA - córtex cingular anterior; E - esquerdo D - direito; pls pulsos; LM - limiar motor; int - intervalo; EEG - electroencephalograma; FP Frontal pole; sess - sessões; Lb - linha de base; ms - messes; sems - semanas 
DISCUSSÃO: Considerando-se que a racionalidade que impulsionou a investigação do uso da EMT na adição à cocaína era calcada na hipótese de que a EMT, ao reduzir a fissura, poderia reduzir seu uso, vê-se, nos últimos três anos, uma inflexão na compreensão dessa racionalidade. Evidências da redução do uso de cocaína com o tratamento com a EMT, cada vez mais robustas, têm acrescentado novos elementos para a compreensão da eficácia da técnica. A melhoria da disfunção hedônica ${ }^{11}$ e do padrão de sono6 dos usuários em tratamento trazem rumos alvissareiros para a investigação dessa díade, qual seja, referência: abuso de cocaína - intervenção: EMT. A melhoria da disfunção glutamatérgica, ponto chave nas adições já é aventada ${ }^{12}$. O uso rotineiro da EMTr para o tratamento de indivíduos que abusavam do uso da cocaína em cenários assistenciais com bons resultados torna mais importante o prosseguimento de estudos para sua implantação de rotina na saúde pública. CONCLUSÃO: Consideramos que o presente trabalho cumpre o objetivo de atualizar dados desde a revisão de 2019, e que estes adicionam às outras intervenções terapêuticas da EMTr, sua utilização no tratamento da dependência de cocaína.

PALAVRAS-CHAVE: Estimulação magnética transcraniana repetitiva. EMTr. Transtornos relacionados à cocaína. Dependência. Drogas.

ABSTRACT | There are no approved medications to treat the harmful use of cocaine ${ }^{1}$ relevant and complex public health problem, what generates demand for effectiveforms ofbiological treatment. The therapeutic use of repetitive transcranial magnetic stimulation (rTMS) to reduce the consumption of psychoactive substances has been explored since 20032,3.
In an integrative review published in 2019, it was found the existence of seven experimental studies that indicated, as a whole, beneficial effects of the use of the technique in user ${ }^{4}$. Since then, new studies of both experimental and observational studies have been published on the subject. In the studies, new outcomeswere examined, such as sleep improvement, in an observational study, and hedonic dysregulation, in an experimental study. From these studies, a more suitable horizon for clinical application of rTMS in the treatment of cocaine addiction in public health is noted. AIMS: To present the results of studies evaluating the efficacy of rTMS in reducing cocaine use since the 2019 review $^{4}$. METHOD: The study by Protasio et al. ${ }^{4}$ reports an integrative review of seven trials conducted from 2007 to 2016, which investigate the use of rTMS in individuals who abuse cocaine. In order to update research findings on the subject, the authors conducted an independent search for publications related to epidemiological studies from 2017 to the moment aimed to evaluate the use of rTMS for the treatment of individuals who abused cocaine use. The search was performed in PubMed/ Medline and Google academic search systems, and the terms Transcranial Magnetic Stimulation AND Cocaine use disorder were used. The search on Google Scholar was considered until the 4th. a page for irrelevance to the theme in the two pages that followed (Figure. 1) RESULTS: Seven studies were found, four experimental and three observational. In two studies, irradiation was profound, and superficial in the others. Theta Burst stimulation was used in two studies. The dorsolateral prefrontal cortex (DLPFC) was the target of choice in five studies. In one study, 2000 pulses were applied and in three, 2400 pulses per session; in one, 1200, and two others, 600 pulses or less. In six studies, a reduction in cocaine use was observed (Table 1). 


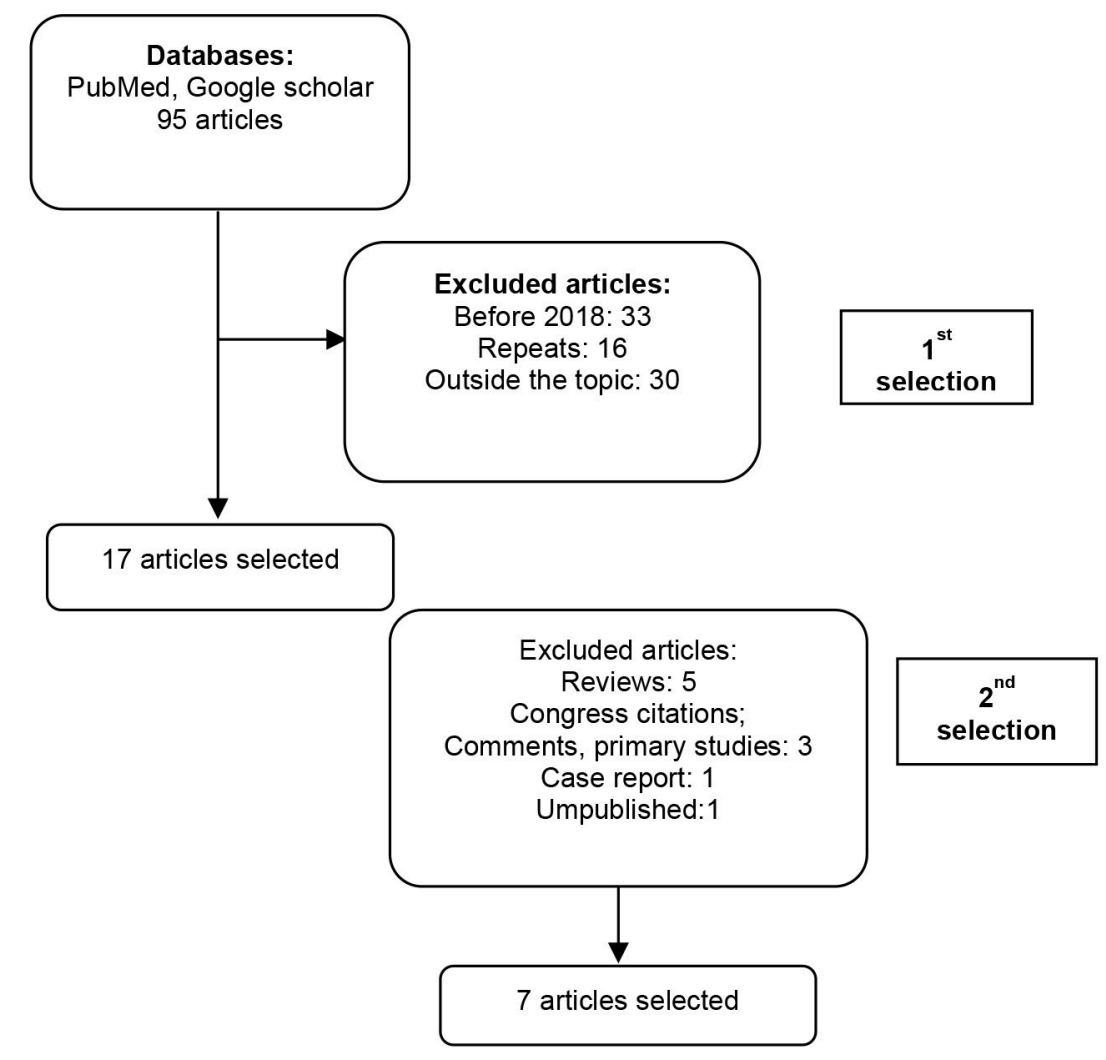


Table 1. Data Experimental Trials Using rTMS on Cocaine Addicts $5-11$

\begin{tabular}{|c|c|c|c|c|c|c|c|}
\hline Study & Design & $\mathbf{N}$ & Sessions & Parameters & Control (C) & $\begin{array}{c}\text { Adverse } \\
\text { Effects }\end{array}$ & Results \\
\hline$\sum_{\substack{\frac{N}{n} \\
\frac{n}{n}}}^{\infty}$ & $\begin{array}{l}\text { Pilot study } \\
\text { Controlled }\end{array}$ & $\begin{array}{l}18 \text { in three } \\
\text { groups } \\
\text { (6 prTMS } \\
\text { AF, } 6 \mathrm{BF}, 6 \mathrm{C})\end{array}$ & 13 & \begin{tabular}{|l|}
$1200 \mathrm{pls} 10 \mathrm{~Hz}$ ou $900 \mathrm{pls}$ \\
$1 \mathrm{~Hz} 40$ trains EMTrp \\
$10 \mathrm{H} / 90-110 \%$ LM, 3 \\
pls/20s MPFC e ACC
\end{tabular} & Placebo coil & $\begin{array}{l}\text { Discomfort at } 120 \% \text { MT before } \\
\text { the start of the study }\end{array}$ & $\begin{array}{l}\text { Reduction of cocaine choice in the high- } \\
\text { frequency MSTr group.* (ses.2 and 3); no } \\
\text { difference in the other groups }\end{array}$ \\
\hline 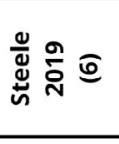 & Open study & 19 & $\begin{array}{l}30 \\
2 / \text { day }\end{array}$ & 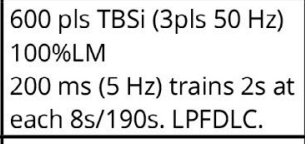 & - & $\begin{array}{l}\text { Mild headache in the majority; } \\
\text { not tolerated }(n=2)\end{array}$ & $\begin{array}{l}9 \text { patients were analyzed. Reduction in the } \\
\text { number of days of use } e^{\star \star *} ; \text { reduction in cocaine } \\
\text { money expenditure }{ }^{* * *} \text {; no qualitative } \\
\text { difference in cocaine use; }\end{array}$ \\
\hline 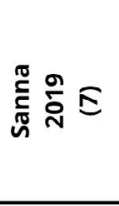 & Pilot study & $\begin{array}{l}25 \text { TBSi } \\
22 \text { prTMS }\end{array}$ & $\begin{array}{l}20 \\
(10 \\
\text { weeks } 1^{\text {a week- }} \\
2 / \text { day/1int. }+4 \\
\text { sess. } \\
1 / \text { day/2weeks } \\
\end{array}$ & $\begin{array}{l}\text { 600pls - TBSi ( } 3 \text { pls } 50 \\
\mathrm{~Hz}) 200-\mathrm{ms} \text { intervals for } \\
2 \mathrm{~s}-(5 \mathrm{~Hz}) \text {. trains de } 2 \mathrm{~s} \\
\text { at each } 10 \mathrm{~s} / 190 \mathrm{~s} / \\
\text { bilateral PFC }\end{array}$ & $\begin{array}{l}2400 \text { pls. } 40 \text { trains } \\
\text { rTMS } 15 \mathrm{~Hz} 60 \\
\text { pls/4s } / 15 \mathrm{~s} \text { int. } \\
\text { bilateral PFC }(20 \\
\text { sess.) }\end{array}$ & $\begin{array}{l}\text { Small discomfort with both } \\
\text { techniques at the beginning of } \\
\text { stimulation }\end{array}$ & $\begin{array}{l}\text { Reduction of consumption* with both } \\
\text { techniques, without difference between them. } \\
\text { Reduction of craving } * * \star \text { with both techniques } \\
\text { in the time factor, but not in the treatment. }\end{array}$ \\
\hline 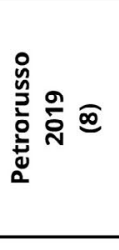 & Open study & 16 & \begin{tabular}{|l|}
28 \\
$(20$ intense phase \\
8 manut phase. \\
2 sess $/$ day $13 \mathrm{~m}$ \\
in t).
\end{tabular} & $\begin{array}{l}2400 \mathrm{pls} 40 \text { trains rTMS } \\
15 \mathrm{hz} / 100 \% \mathrm{MT} \\
60 / 15 \mathrm{~s} \text { int.LPFDLC. }\end{array}$ & - & No Adverse effects & 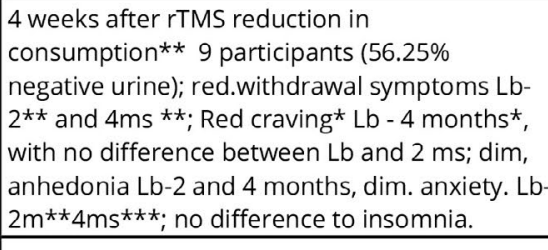 \\
\hline 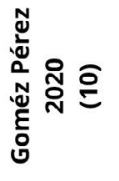 & $\begin{array}{l}\text { Open study } \\
\text { Retrospective } \\
\text { Observational } \\
\text { Randomized }\end{array}$ & 87 & $\mid$\begin{tabular}{l|}
34 \\
$(10$ in 5 days +24 \\
in 12 weeks \\
$(2$ sess $/$ day $45-$ \\
$60 \mathrm{~m}$ int. $)$
\end{tabular} & $\begin{array}{l}\text { 2400pls 40trains rTMS } \\
\text { 15hz/100\% TM } \\
60 / 15 \mathrm{~s} \text { int. .LPFDLC. }\end{array}$ & $\begin{array}{l}10 \text { patients on the } \\
\text { waiting list who } \\
\text { received rTMS. }\end{array}$ & No Adverse effects & $\begin{array}{l}\text { Red. consumption } * * \star 30 \text { d. }(71.9 \%) 90 \text { d. }(66 \%) \\
\text { after rTMS, improvement in sleep quality***, } \\
\text { which was maintained for } 90 \text { days after rTMS/ } \\
\text { associated with the number of rTMS sessions; } \\
\text { Red. craving*** }\end{array}$ \\
\hline 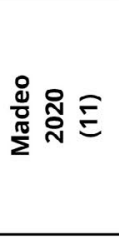 & $\begin{array}{l}\text { retrospective } \\
\text { observational } \\
\text { Cohort study }\end{array}$ & 284 & $\begin{array}{l}\text { ( } 10 \text { in } 5 \text { days }+24 \\
\text { in } 12 \text { weeks } \\
(2 \text { sess/day } 13 m \\
\text { int.). }\end{array}$ & $\begin{array}{l}\text { 2400pls 40trains rTMS } \\
\text { 15hz/100\% LM } \\
60 / 15 \text { s int. .LPFDLC. }\end{array}$ & $\begin{array}{l}\text { Relapse time } 174 \\
\text { patients in } \\
\text { traditional ttm.15 } \\
\text { years previously in } \\
\text { US. }\end{array}$ & $\begin{array}{l}\text { Headache } 23 \text {, hypomania } 4 \text {, } \\
\text { anxiety } 2 \text {,irrit.2, toothache } 2 \text {, } \\
\text { discomfort } 1 \text {, angioedema and } \\
\text { hives } 1 \text {, distraction } 1 \text {, dizziness } \\
1 \text {, nausea } 1 \text {, nausea and } \\
\text { numbness } 1 \text {, convulsion } 1 \text {, } \\
\text { hypomanic episode } 1 .\end{array}$ & $\begin{array}{l}\text { Increased abstinence time ( } 91 \text { days) ( } 95 \% \\
\text { confidence interval } 70-109 \text { days) compared to } \\
\text { patients on traditional treatment (51) (95\% } \\
\text { confidence interval } 39-78 \text { days). The difference } \\
\text { was sustained } 80 \text { days after hospital discharge. }\end{array}$ \\
\hline ڤั้ ํํํ & $\begin{array}{l}\text { Retrospective } \\
\text { investigative } \\
\text { study }\end{array}$ & 10 & $\begin{array}{l}10 \text { sessions for } 2 \\
\text { weeks }\end{array}$ & $\begin{array}{l}2000 \text { pls } 20 \text { trains rTMS } \\
15 \mathrm{~Hz} / 100 \% \mathrm{MT}, 30 \mathrm{~s} / 2 \mathrm{~s} \\
\text { int. LPFDLC. }\end{array}$ & - & - & $\begin{array}{l}\text { craving reduction **, reduction of depression } \\
\text { scores *, no difference in anxiety score. }\end{array}$ \\
\hline
\end{tabular}

$p \leq 0.05 * ; \leq 0.01 * * ; p \leq 0.001 * * *$

Key: AF - alta frequência; BF - baixa frequência; C -Controle; EMTr - Estimulação Magnética Transcraniana repetitiva; EMTrp - EMTr profunda; TBSc - theta burst stimulation cotínua; TBSi - theta busrt intermitente; CPF - córtex prefrontal; CPFDL - cortex prefrontal dorsolateral; CPFM - cortex; pré-frontal medial; CCA - córtex cingular anterior; E - esquerdo D - direito; pls pulsos; LM - limiar motor; int - intervalo; EEG - electroencephalograma; FP Frontal pole; sess - sessões; Lb - linha de base; ms - messes; sems - semanas; 
DISCUSSION: Considering that the rationale that stimulated the investigation of the use of TMS in the addition to cocaine was based on the hypothesis that TMS, by reducing craving, could reduce its use, it is perceived, in the last three years, an inflection in the understanding of this rationale. Evidence of the reduction of cocaine use with TMS treatment, increasingly robust, has added new elements to understanding the effectiveness of the technique. The improvement of hedonic dysfunction ${ }^{12}$ and sleep pattern ${ }^{9}$ of users undergoing treatment bring more positive directions for the investigation of this dyad, that is, reference: cocaine abuse - intervention: TMS. The improvement of glutamatergic dysfunction, a key point in additions is already suggested ${ }^{13}$. The routine uses of rTMS for the treatment of individuals who abused cocaine use in assistance scenarios with good results makes it more important to continue studies for their routine implementation in public health. CONCLUSION: We believe that the present study fulfills the objective of updating data since the 2019 review and that these add to the other therapeutic interventions of rTMS, its use in the treatment of cocaine addiction.

KEYWORDS: Repetitive transcranial magnetic stimulation. rTMS. Cocaine-related disorders. Dependence. Drugs.

\section{Contribuições dos autores}

Protasio MIB e Silva JPL foram responsáveis pela pesquisa nas bases de dados, redação do texto e revisão final do resumo.

\section{Conflito de interesse}

Nenhum conflito financeiro, legal ou político envolvendo terceiros (governo, empresas e fundações privadas, etc.) foi declarado para nenhum aspecto do trabalho submetido (incluindo, mas não se limitando a subvenções e financiamentos, participação em conselho consultivo, desenho de estudo, preparação de manuscrito, análise estatística, etc.).

\section{Referências}

1. Volkow ND. Personalizing the treatment of substance use disorders. Am J Psychiatry. 2020;177(2):113-6. https://doi. org/10.1176/appi.ajp.2019.19121284

2. Lefaucheur JP, André-Obadia N, Antal A, Ayache SS, Baeken C, Benninger $\mathrm{DH}$, et al. Evidence-based guidelines on the therapeutic use of repetitive transcranial magnetic stimulation (rTMS). Clin Neurophysiol. 2014;125(11):2150-206. https://doi.org/10.1016/j. clinph.2014.05.021

3. Protasio MI, Silva JP, Arias-Carrión O, Nardi AE, Machado S, Cruz MS. Repetitive transcranial magnetic stimulation to treat substance use disorders and compulsive behavior. CNS Neurol Disord Drug Targets. 2015;14(3):331-40. https://doi.org/10.2174/1 871527314666150318114043

\section{Protasio MI, Silva JP, Machado S, Chagas SV, Murillo-Rodriguez E, Cruz MS. The Effects of Repetitive Transcranial Magnetic Stimulation in Reducing Cocaine Craving and Use. Addict Disord Their Treat. 2019;18(4):212-22. https://doi.org/10.1097/ ADT.0000000000000169}

5. Martinez D, Urban N, Grassetti A, Chang D, Hu MC, Zangen $A$, et al. Transcranial magnetic stimulation of medial prefrontal and cingulate cortices reduces cocaine self-administration: a pilot study. Front Psychiatry. 2018;9:80. https://doi.org/10.3389/ fpsyt.2018.00080

6. Steele VR, Maxwell AM, Ross TJ, Stein EA, Salmeron BJ. Accelerated intermittent theta-burst stimulation as a treatment for cocaine use disorder: a proof-of-concept study. Front Neurosci. 2019;13:1147. https://doi.org/10.3389/fnins.2019.01147

7. Sanna A, Fattore L, Badas P, Corona G, Cocco V, Diana M. Intermittent theta burst stimulation of the prefrontal cortex in cocaine use disorder: a pilot study. Front Neurosci. 2019;13:765. https://doi.org/10.3389/fnins.2019.00765

\section{Pettorruso M, Martinotti G, Santacroce R, Montemitro C, Fanella F, Di Giannantonio M. rTMS reduces psychopathological burden and cocaine consumption in treatment-seeking subjects with cocaine use disorder: an open label, feasibility study. Front Psychiatry. 2019;10:621. https://dx.doi. org/10.3389\%2Ffpsyt.2019.00621}

9. Gómez Pérez LJ, Cardullo S, Cellini N, Sarlo M, Monteanni T, Bonci A, et al. Sleep quality improves during treatment with repetitive transcranial magnetic stimulation (rTMS) in patients with cocaine use disorder: a retrospective observational study. BMC psychiatry. 2020;20(1):153. https://doi.org/10.1186/s12888020-02568-2 
10. Madeo G, Terraneo A, Cardullo S, Gómez Pérez LJ, Cellini $\mathrm{N}$, Sarlo $\mathrm{M}$, et al. Long-term outcome of repetitive transcranial magnetic stimulation in a large cohort of patients with cocaine-use disorder: an observational study. Front Psychiatry. 2020;11:158. https://doi.org/10.3389/fpsyt.2020.00158

11. Soomro H, O'Neill-Kerr A, Neal L, Griffiths C, De Vai R. Transcranial Magnetic Stimulation for the Treatment of Cocaine Addiction. Open J. Depress. 2020;9(2):26-30. https://doi. org/10.4236/ojd.2020.92003
12. Pettorruso M, Spagnolo PA, Leggio L, Janiri L, Di Giannantonio $M$, Gallimberti $L$, et al. Repetitive transcranial magnetic stimulation of the left dorsolateral prefrontal cortex may improve symptoms of anhedonia in individuals with cocaine use disorder: A pilot study. Brain Stimul. 2018;11(5):1195-7. https://doi.org/10.1016/j. brs.2018.06.001

13. Moretti J, Poh EZ, Rodger J. rTMS-induced changes in glutamatergic and dopaminergic systems: relevance to cocaine and methamphetamine use disorders. Front Neurosci. 2020;14. https://doi.org/10.3389/fnins.2020.00137 